\title{
PERSPECTIVE
}

\section{Revised D-A-CH intake recommendations for folate: how much is needed?}

\author{
MB Krawinkel ${ }^{1}$, D Strohm² ${ }^{2}$ A Weissenborn ${ }^{3}$, B Watzl ${ }^{4}$, M Eichholzer $^{5}$, K Bärlocher $^{6}$, I Elmadfa ${ }^{7}$, E Leschik-Bonnet ${ }^{2}$ and H Heseker $^{8}$
}

The D-A-CH reference value (D-A-CH arises from the initial letters of the common country identification for the countries Germany (D), Austria (A) and Switzerland (CH)) for folate equivalents had been set at $400 \mu \mathrm{g} / \mathrm{d}$ for adults in the year 2000 . By that time, the prevention of cardiovascular diseases through reduction of homocysteine was considered an important target of the reference value. Since that time a number of research papers revealed that in spite of an inverse association between folate-rich diet and chronic diseases, a preventive effect of folic acid intake on cardiovascular events was not supported by randomized controlled trials, and the reduction of plasma homocysteine levels to around 10-12 $\mu \mathrm{mol} / \mathrm{l}$ did not reduce the risk for thromboembolic and cardiovascular diseases in persons already affected by these diseases. These results together with the observation that folate intakes below $400 \mathrm{\mu g} / \mathrm{d}$ result in a sufficient folate status justified a review of the current literature and-consequently-a reduction of the reference value to $300 \mu \mathrm{g} / \mathrm{d}$ for adults. This reference value is expressed as dietary folate equivalents that take into account the difference in bioavailability between folic acid and all types of folates in food. The recommendation to take a daily supplement of $400 \mu \mathrm{g}$ of synthetic folic acid for women who intend to get pregnant and until the end of the first trimester of pregnancy is maintained.

European Journal of Clinical Nutrition (2014) 68, 719-723; doi:10.1038/ejcn.2014.45; published online 2 April 2014

Recommendations for the intake of folate equivalents show a certain variance over time and over regions. In 2000, the D-A-CH societies recommended a daily intake of $400 \mu \mathrm{g} / \mathrm{d}$ for adults. ${ }^{1}$ The same value had been set earlier by the USA, Canada ${ }^{2}$ and by Australia and New Zealand. ${ }^{3}$ It was also accepted by the World Health Organization (WHO) and the Food and Agriculture Organization (FAO) of the United Nations. ${ }^{4}$ However, some countries recommend $300 \mu \mathrm{g} / \mathrm{d}$ (for example, the Netherlands, Ireland ${ }^{6}$ and France ${ }^{7}$ ), and the United Kingdom goes for $200 \mu \mathrm{g} / \mathrm{d}$ only. ${ }^{8}$ Table 1 indicates the various different recommendations.

This variance of recommendations results from the fact that the scientific basis allows for a certain variation: for example, in the United States and other countries, red blood cell folate in conjunction with plasma folate and total homocysteine concentrations were used, whereas in the UK red blood cell folate and autopsied liver folate concentrations were used as an indicator to derive the reference values for folate. ${ }^{2,8}$ Furthermore, it depends on what is considered an adequate status not just based on the absence of signs of folate deficiency (hyperchromic macrocytic anemia, polyneuropathy) but on plasma and/or erythrocyte folate concentrations and plasma homocysteine level required to maintain health. However, a minimal intake for maintaining a normal status is mandatory but not sufficient for itself.

A number of other factors have to be considered when estimating folate requirements. These include the variety of folates with different bioavailability and functionality and the differentiation between synthetic folic acid and dietary folate, as well as the increasing knowledge about the prevalence of methyltetrahydrofolate reductase (MTHFR) polymorphisms and receptor defects, although their relevance in folate intake recommendations is not fully clear yet. ${ }^{18}$ In principal, reference values would need to be defined for each and every variety of folate (for example, various forms of pteroylpolyglutamates). This differentiation would be all but useful for dietary advice-but it requires some consideration when reference values are to be based on scientific evidence.

Folate requirements and recommendations for folate intake are expressed as dietary folate equivalents that adjust for the greater degree of absorption of folic acid compared with folate naturally found in foods ( $1 \mu \mathrm{g}$ of folate equals $0.6 \mu \mathrm{g}$ folic acid added to food or taken with food or $0.5 \mu \mathrm{g}$ folic acid (as a supplement) taken on an empty stomach). ${ }^{2,19}$

According to data from the German National Nutrition Survey II, the median intake of folate equivalents of 14-80-year-old men living in Germany was $207 \mu \mathrm{g} / \mathrm{d}$ (5\% percentile (P5)-95\% percentile (P95) 116-349 $\mu \mathrm{g}$ ). In women of the same age, the median intake was $184 \mu \mathrm{g} / \mathrm{d}$ (P5-P95 104-304 $\mu \mathrm{g}$ ) (Heuer T, Folate intake in adolescence and adults in the NVSIl; personal communication). The mean daily intake of men living in Austria was $255 \mu \mathrm{g}$ in 18-25-year-olds, $197 \mu \mathrm{g}$ in 25-51-year-olds, $222 \mu \mathrm{g}$ in 51-65-year-olds and $203 \mu \mathrm{g}$ in 65-80-year-olds. In women of the same age groups, it was 229, 216, 193 and $194 \mu \mathrm{g} / \mathrm{d}^{20}$

The D-A-CH reference value of $400 \mu \mathrm{g}$ of folate equivalents for adults published in the year 2000 was based on the observation that such an intake amount leads to a significant reduction of homocysteine level and on expectations that thereby the risk for cardiovascular diseases would be reduced. ${ }^{21-23}$ Since that time, a number of studies has led to a different perspective, as none of

\footnotetext{
${ }^{1}$ Institute of Nutritional Sciences, Justus-Liebig-University, Giessen, Germany; ${ }^{2}$ Deutsche Gesellschaft für Ernährung e. V., Bonn, Germany; ${ }^{3}$ Bundesinstitut für Risikobewertung, Berlin, Germany; ${ }^{4}$ Max-Rubner-Institut, Karlsruhe, Germany; ${ }^{5}$ Institut für Sozial- und Präventivmedizin, Universität Zürich, Zürich, Switzerland; ${ }^{6}$ Tanneichenstrasse 10,9010 St. Gallen, Switzerland; ${ }^{7}$ Institute of Nutritional Sciences, University of Vienna, Wien, Austria and ${ }^{8}$ Department of Sports and Health, Universität Paderborn, Paderborn, Germany. Correspondence: Professor MB Krawinkel, Institute of Nutritional Sciences, Justus-Liebig-University, Wilhelmstrasse 20, Giessen D-35392, Germany. 
Table 1. Reference values for folate/folate equivalents for adults from different international societies and organizations

\begin{tabular}{|c|c|c|c|}
\hline Society & Reference value & Indicators & $\begin{array}{l}\text { References and studies primarily } \\
\text { considered }\end{array}$ \\
\hline United Kingdom & $200 \mu \mathrm{g}$ folate & $\begin{array}{l}\text { Red blood cell folate }(>317 \mathrm{nmol} / \mathrm{l}) \text {, autopsied liver } \\
\text { folate }(>3 \mu \mathrm{g} / \mathrm{g})\end{array}$ & $\begin{array}{l}\text { SACN }{ }_{i}^{8} \text { Herbert et al. }{ }^{9} \text { Hoppner } \\
\text { and Lampi, }{ }^{10}\end{array}$ \\
\hline Scientific Committee on Food ${ }^{a}$ & $200 \mu \mathrm{g}$ folate & Red blood cell folate (>340 $\mathrm{nmol} / \mathrm{l})$ & $\begin{array}{l}\text { SCF } ;^{11} \text { Banerjee et al.; }{ }^{12} \text { Herbert } \\
\text { et al., }{ }^{9} \\
\text { Sauberlich et } \text { al. }{ }^{13}\end{array}$ \\
\hline USA, Canada & $400 \mu \mathrm{g}$ folate equivalents & $\begin{array}{l}\text { Primary: red blood cell folate }(>305 \mathrm{nmol} / \mathrm{l}) \\
\text { secondary: serum folate }(>7 \mathrm{nmol} / \mathrm{l}) \text {, total } \\
\text { homocysteine }(<16 \mu \mathrm{mol} / \mathrm{l})\end{array}$ & IOM; ${ }^{2} \mathrm{O}^{\prime}$ Keefe et al. ${ }^{14}$ \\
\hline $\begin{array}{l}\text { Germany, Austria, } \\
\text { Switzerland (2000) }\end{array}$ & $400 \mu \mathrm{g}$ folate equivalents & $\begin{array}{l}\text { Red blood cell folate, serum folate, total } \\
\text { homocysteine }\end{array}$ & DGE; ${ }^{1}$ O'Keefe et al. ${ }^{14}$ \\
\hline $\begin{array}{l}\text { Germany, Austria, } \\
\text { Switzerland (2013) }\end{array}$ & $300 \mu \mathrm{g}$ & Red blood cell folate, serum folate & $\begin{array}{l}\text { Herbert et al.; }{ }^{9} \text { Sauberlich et al.; }{ }^{13} \\
\text { Milne et al.:; }{ }^{16} \mathrm{DGE}^{47}\end{array}$ \\
\hline $\mathrm{FAO}, \mathrm{WHO}$ & $400 \mu \mathrm{g}$ folate equivalents & $\begin{array}{l}\text { Primary: red blood cell folate }(>340 \mathrm{nmol} / \mathrm{l}) ; \\
\text { secondary: serum folate, total homocysteine } \\
\left(\text { analog to } \mathrm{IOM}^{2}\right)\end{array}$ & $\mathrm{FAO} / \mathrm{WHO}^{4}{ }^{4} \mathrm{IOM}^{2}$ \\
\hline Nordic countries & $300 \mu \mathrm{g}$ folate & $\begin{array}{l}\text { Red blood cell folate }(>317 \mathrm{nmol} / \mathrm{l}) \text {, serum folate } \\
(>6.8 \mathrm{nmol} / \mathrm{l}) \text {, total homocysteine }(9.3-16.3 \mu \mathrm{mol} / \mathrm{l})\end{array}$ & $\begin{array}{l}\text { Nordic Council of Ministers; }{ }^{15} \\
\text { Herbert et al. } ;^{9} \text { Milne et al.; }{ }^{16} \\
\text { Sauberlich et al. }{ }^{13}\end{array}$ \\
\hline Australia and New Zealand & $400 \mu \mathrm{g}$ folate equivalents & $\begin{array}{l}\text { Primary: red blood cell folate; secondary: serum } \\
\text { folate, total homocysteine }\end{array}$ & NHMRC; ${ }^{3}$ O'Keefe et al. ${ }^{14}$ \\
\hline The Netherlands & $300 \mu \mathrm{g}$ folate equivalents & $\begin{array}{l}\text { Red blood cell folate, serum folate, total } \\
\text { homocysteine }(<15 \mu \mathrm{mol} / \mathrm{l})\end{array}$ & $\begin{array}{l}\text { Health Council of the } \\
\text { Netherlands; }\end{array}$ \\
\hline France & $300 \mu \mathrm{g}$ folate & $\begin{array}{l}\text { Red blood cell folate, serum folate, total } \\
\text { homocysteine }\end{array}$ & Guéguen et al. ${ }^{17}$ \\
\hline
\end{tabular}

the large prevention-oriented intervention studies (for example, NORVIT, ${ }^{24}$ HOPE $^{25}$ and VISP 26 among others] could prove an advantage of a supplementary intake of folic acid (and other B vitamins) for secondary or tertiary prevention of cardiovascular disease and stroke. ${ }^{27,28}$ Therefore, doubts emerged about a preventive effect of folate/folic acid intake and respective plasma homocysteine levels $<10-12 \mu \mathrm{mol} / \mathrm{l}$ on cardiovascular diseases.

Therefore, the aim of the revision of the dietary reference values for folate was to reevaluate the requirements for different population groups based on the cognition that a low homocysteine concentration does not represent the primary target in deriving folate reference values.

For determining folate requirements in adults metabolic balance studies that primarily examined serum folate concentrations were considered. Furthermore, a literature review was done for identifying epidemiological studies that had assessed folate intake and status in healthy adults. This also included a comparison of intake and status data from Austria and Germany. ${ }^{29}$

Developing a new reference value for folate intake required to define the target biomarkers for a supply that reflects adequacy of metabolic functions. As the serum folate concentration reflects the recent folate intake quite well and is not much affected by other factors, serum folate was acknowledged as a useful indicator and a level of $\geqslant 10 \mathrm{nmol} / \mathrm{l}(4.4 \mu \mathrm{g} / \mathrm{l})$ as marker of a sufficient supply. ${ }^{30}$ Therefore, deriving the reference value for adults was based on studies that primarily examined intake of folate/folic acid and serum folate concentrations.

Erythrocyte folate levels are regarded as an indicator for folate stores of the body, and a level $\geqslant 340 \mathrm{nmol} / \mathrm{l}(\geqslant 150 \mu \mathrm{g} / \mathrm{l})$ is considered adequate. However, as erythrocyte folate measurements are prone to alterations by interferences, ${ }^{31}$ this indicator was only used as a secondary, functional variable. Subclinical deficiency is defined as a drop below $340 \mathrm{nmol} / \mathrm{l}^{30,32,33}$

Folate deficiency inhibits the metabolic pathway from homocysteine to methionine-but plasma homocysteine is not considered suitable as a sole marker for the folate status. ${ }^{2,34,35}$ This is because not every increase of plasma homocysteine is specifically related to folate intake. ${ }^{25}$ In healthy adults consuming sufficient amounts of vitamin $B_{2}, B_{6}, B_{12}$ and folate, plasma homocysteine concentrations are $<12 \mu \mathrm{mol} / \mathrm{l}$. Therefore, a plasma homocysteine level $<12 \mu \mathrm{mol} / \mathrm{l}$ was considered a secondary objective.

As there is no report indicating folate deficiency in fully breastfed children, ${ }^{36}$ the folate content of breast milk of $80 \mu \mathrm{g} / \mathrm{l}^{37}$ is considered an appropriate basis for deriving a reference value for infants. There is no experimental data investigating folate requirement in toddlers, children and adolescence. Hence, reference values for these groups were estimated by extrapolating from adults following the method proposed by the Institute of Medicine (IOM). ${ }^{2}$

The former derivation of reference values for the folate intake was mainly based on the study by O'Keefe et al. ${ }^{14}$ in which the response to a constant intake of three levels of folic acid $(170,270$ or $370 \mu \mathrm{g} / \mathrm{d}$ ) in combination with $30 \mu \mathrm{g}$ folate from foods was examined in women. On the basis of this study, a minimal intake of $320 \mu \mathrm{g}$ of folate equivalents per day was regarded necessary and this led to the intake recommendation of $400 \mu \mathrm{g} / \mathrm{d} .^{1}{ }^{1}$ It was now concluded that the minimal intake of $320 \mu \mathrm{g}$ folate equivalents used in this study was considerably higher than that in other studies. Earlier studies investigating the folate requirement clearly showed that $<320 \mu \mathrm{g}$ folate equivalents is sufficient for a good folate supply. Therefore, the study from O'Keefe et al. ${ }^{14}$ was not considered for deriving the reference value any more.

From metabolic balance studies ${ }^{9,13,16}$ it was concluded that the minimal intake for preventing a macrocytic hyperchromic anemia is $50 \mu \mathrm{g}$ folic acid per day and that the desired folate status (plasma levels: $\geqslant 10 \mathrm{nmol} / \mathrm{l}$ ) can be achieved with about $200 \mu \mathrm{g}$ of folate equivalents per day. Taking a certain underestimation of the folate content of foods due to analytical limitations into account, $10 \%$ were added to arrive at $220 \mu \mathrm{g} / \mathrm{d}$ as an estimated average requirement (EAR). A further $30 \%$ was added to ensure that $97.5 \%$ of the population achieve an adequate folate status, and the result was rounded to an intake value of $300 \mu \mathrm{g}$ per day for adults up to 65 years of age.

This reference value is supported by folate intake and status data from Austria where women and men achieved plasma folate 
concentrations $>19.6$ and $16.6 \mathrm{nmol} / \mathrm{l}$ with an average daily intake of 211 and $212 \mu \mathrm{g}$ folate equivalents, respectively. ${ }^{20}$ Data about folate intake and serum values of the German population show a similar picture, although these results date back to about 10 years ago. $^{29}$

Furthermore, a convincing number of observational studies found that an adequate folate supply can be achieved with intakes of folate equivalents below $300 \mu \mathrm{g} / \mathrm{d}^{38-43}$ For example, in a mixed group of men and postmenopausal women between 50 and 70 years of age a folate intake of about $200 \mu \mathrm{g} / \mathrm{d}$ was associated with serum folate levels of $11-12 \mathrm{nmol} / \mathrm{l}$ and erythrocyte folate of $>600 \mathrm{nmol} / \mathrm{l}$. These probands had plasma homocysteine levels between 12.5 and $13 \mu \mathrm{mol} / \mathrm{I}^{40}$ No effect of a daily supplement of even $0.8 \mathrm{mg}$ folic acid on DNA methylation was seen in this study, and also stratification according to the MTHFR C677T genotypes CC, CT and TT did not reveal a significant effect of the folic acid supplementation. ${ }^{40}$ Another survey in healthy men, 50-70 years of age, showed an association between a mean folate intake of $229 \mu \mathrm{g} / \mathrm{d}$, serum folate levels $>20 \mathrm{nmol} / \mathrm{l}$ and a mean plasma homocysteine level of 10.9 umol/l. ${ }^{41}$

Altogether, results of epidemiological studies including data from Austria and Germany demonstrate that, with an intake of $300 \mu \mathrm{g}$ dietary folate equivalents, concentrations of serum folate are maintained at levels representing a sufficient folate supply.

There is no indication of an altered folate requirement in adults 65 years and older. Hence, the recommended dietary intake of folate equivalents for older adults does not differ from that for the younger age groups and is thus also set at $300 \mu \mathrm{g} / \mathrm{d}$.

As for toddlers, children and adolescents empirical data about their folate requirements are missing, the EAR for adults has been used for calculating age-specific recommendations.

For the calculation of the EAR for children and adolescents the algorithm of the IOM was used: ${ }^{2}$

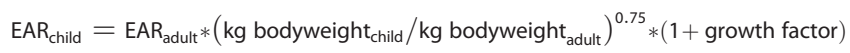

$E A R_{\text {adult }}=220 \mu \mathrm{g} ; \mathrm{kg}$ bodyweight ${ }_{\text {adult }}$ refers to $74 \mathrm{~kg}$ for men and $59 \mathrm{~kg}$ for women; the reference body weights for children and growth factors applied are shown in Table 2 which indicates the data used in the algorithm and the results of the calculations.

For defining an adequate intake for infants, the average concentration of about $80 \mu \mathrm{g} / \mathrm{l}$ folate in breast milk was used. ${ }^{37,44}$ On the basis of a mean ingestion of $750 \mathrm{ml}$ breast milk per day, an estimated $60 \mu \mathrm{g} / \mathrm{d}$ was set for exclusively breastfed infants.

The composition of breast milk is adapted to the infant's needs and supplies the infant with essential nutrients for growth and a healthy development in the first half year of life. Depending on the individually different development of infants, it is recommended to exclusively breastfeed children for 4-6 months, that means no other liquid besides breast milk should be given until the beginning of the 5th or 7th month of life. Infants showing healthy growth pattern can and should be exclusively breastfed, that is without the inclusion of other liquid or complimentary food for 6 months. ${ }^{45,46}$

Regardless of the recommendations for breastfeeding, the D-A$\mathrm{CH}$ reference values for nutrient intake differentiate between the age groups 0 until the end of the 4 th month of life and the beginning of the 5 th month to the end of the 12th month of life. Thus, the value of $60 \mu \mathrm{g} / \mathrm{d}$ applies for infants from 0 to 4 months. But, this intake level is also considered sufficient for exclusively breastfed infants up to 6 months.

The reference value for infants who receive complementary foods from 5 (or 7) months to 12 months was derived by considering the reference value for energy of $700 \mathrm{kcal}$ for this age group ${ }^{47}$ and accounting for the nutrient density of breast milk $\left(12 \mu \mathrm{g}\right.$ folate $/ 100 \mathrm{kcal}$ breast milk). ${ }^{37}$ Thus, for infants in the
Table 2. Intake reference values for children and adolescents derived from the revised EAR for adults

Bodyweight $_{\text {child }}$ Growth EAR-calculation $+30 \%$ New reference $(\mathrm{kg})$ factor based on IOM $(\mu \mathrm{g})$ value $(\mu \mathrm{g})$ $(\mu \mathrm{g})$

\begin{tabular}{|c|c|c|c|c|c|}
\hline \multicolumn{6}{|c|}{$1-<4$ years } \\
\hline M & 13.5 & 0.3 & 79.8 & 103.8 & \multirow[t]{2}{*}{120} \\
\hline $\mathrm{F}$ & 13.0 & 0.3 & 92 & 119.6 & \\
\hline \multicolumn{6}{|c|}{$4-<7$ years } \\
\hline M & 19.7 & 0.15 & 93.8 & 121.9 & \multirow[t]{2}{*}{140} \\
\hline $\mathrm{F}$ & 18.6 & 0.15 & 106.4 & 138.4 & \\
\hline \multicolumn{6}{|c|}{$7-<10$ years } \\
\hline M & 26.7 & 0.15 & 117.8 & 153.1 & \multirow[t]{2}{*}{180} \\
\hline $\mathrm{F}$ & 26.7 & 0.15 & 139.6 & 181.5 & \\
\hline \multicolumn{6}{|c|}{$10-<13$ years } \\
\hline M & 37.5 & 0.15 & 152 & 197.5 & \multirow[t]{2}{*}{240} \\
\hline $\mathrm{F}$ & 39.2 & 0.15 & 186.2 & 242 & \\
\hline \multicolumn{6}{|c|}{$13-<15$ years } \\
\hline M & 50.8 & 0.15 & 190.8 & 248.1 & \multirow[t]{2}{*}{300} \\
\hline$F$ & 50.3 & 0.15 & 224.5 & 291.8 & \\
\hline \multicolumn{6}{|c|}{$15-<19$ years } \\
\hline M & 67.0 & 0.15 & 234.8 & 305.3 & \multirow[t]{2}{*}{300} \\
\hline $\mathrm{F}$ & 58.0 & 0 & 217.2 & 282.4 & \\
\hline
\end{tabular}

second half year a daily intake of $85 \mu \mathrm{g}$ folate equivalents is recommended.

During pregnancy an estimated extra amount of $200 \mu \mathrm{g}$ folate equivalents per day is required for the development of the fetus. Adding this extra amount to an adult's average requirement of $220 \mu \mathrm{g} / \mathrm{d}$ and providing for another $30 \%$ to make sure that $97.5 \%$ of the population group of pregnant women achieve an adequate folate status, a recommended dietary intake of $550 \mu \mathrm{g} / \mathrm{d}$ folate equivalents was derived for pregnant women.

Lactating women deliver $60 \mu \mathrm{g}$ folate with $750 \mathrm{ml}$ breast milk. Considering folate's bioavailability of $50 \%$, an estimated additional intake of $120 \mu \mathrm{g} / \mathrm{d}$ is required to compensate for the loss of folate through breast milk. This amount was added to the adults mean requirement of $220 \mu \mathrm{g} / \mathrm{d}$ and with the above-mentioned addition of $30 \%$, the recommended dietary intake of folate equivalents was rounded to $450 \mu \mathrm{g} / \mathrm{d}$ for lactating women.

Continued strong support is given to the recommendation of a $400 \mu \mathrm{g}$ folic acid supplement to be taken by women who intend to get pregnant and until the end of the first trimester of the pregnancy to decrease the risk for a child with neural tube defect. The preventive effect of this supplement is beyond doubt-even in populations with a high dietary folate intake (Krawinkel $\mathrm{M}$ et al. Unpublished data of a study about folic acid intake of women with children affected by NTD and healthy children in Cairo, Egypt, 2013). ${ }^{29,32,48-50}$

Reference values for nutrient intake are suggested amounts that are assumed to

- Protect nearly all healthy individuals in a population from deficiency-related conditions

- Ensure optimal physiological and psychological performance, and

- Create a certain body reserve $e^{51}$

The purpose of the recommendations for the intake of folate equivalents is to give the general population an orientation on 
how much of the nutrient should be ingested with the daily diet. Therefore, the primary definition of the folate reference value is based on the proven or assumed need for the normal function of cells, tissues and the whole organism.

It has been postulated that reference values should be entirely based on scientific evidence. ${ }^{52}$ As much as that is desirable, this postulate cannot be considered exclusive. We know too little about nutrient interactions and the role of the food in context of bioactive plant substances to speak of full scientific evidence. This does not mean that such information would not be needed, but at present there is no research into this direction.

In medicine, the absence of specific signs and symptoms of inadequate supply or intake are indicative for meeting the needs. In nutritional science, the physiologically defined minimum and/or maximum requirements provide such evidence-based orientation. The knowledge about these physiologically defined minimum and/or maximum requirements, or rather the primary parameters defining requirements change over time as science proceeds. This was the case in defining nutrient reference values for folate intake. Scientific findings within recent years regarding the relevance of folate/folic acid for homocysteinelowering interventions and disease prevention as well as new epidemiological data regarding folate intake and supply required a reevaluation of the scientific basis for folate requirement.

There have been no health risks observed with a higher intake of dietary folate. However, regarding folic acid, adverse effects associated with high intakes such as the possible progression of neurological symptoms and vitamin $B_{12}$ deficiency were used by the European Food Safety Authority ${ }^{53}$ and other international authorities as a basis to derive an upper intake level even at a time when the potential risks of a daily overdose were not fully understood. This led to the definition of an upper intake level of $1000 \mu \mathrm{g}$ folic acid per day for adults and between 200 and $800 \mu \mathrm{g}$ folic acid per day for children aged 1-17 years. ${ }^{53,54}$ The IOM also defined an upper intake level of $1000 \mu \mathrm{g}$ folic acid per day for adults. $^{2}$

To conclude, the DGE expert group recommended reducing the reference value for folate equivalents from 400 to $300 \mu \mathrm{g} / \mathrm{d}$. The recommendation of a daily supplement of $400 \mu \mathrm{g}$ folic acid for women intending to get pregnant until the end of the first trimester of the pregnancy remains valid and highly relevant for decreasing the risk for a child with neural tube defect. It deserves more attention by public health authorities because still too few women adhere to this recommendation. ${ }^{47}$

\section{CONFLICT OF INTEREST}

The authors declare that they have no conflict of interest regarding folate intake recommendations. The German Nutrition Society (DGE) convened the group who met several times and was supported by DGE, ÖGE and SGE for travel expenses without any obligation regarding the results. The DGE receives funds from the German Federal Ministry of Nutrition, Agriculture and Consumer Protection which also exerted no influence on the results of the group.

\section{REFERENCES}

1 Deutsche Gesellschaft für Ernährung (DGE). DACH-Referenzwerte für die Nährstoffzufuhr. 1. Aufl. Frankfurt am Main: Umschau/Braus, 2000.

2 Institute of Medicine (IOM). Dietary Reference Intakes for Thiamin, Riboflavin Niacin, Vitamin B b6 s, Folate, Vitamin B12, Pantothenic acid, Biotin, and Choline. National Academy Press: Washington, DC, 1998.

3 National Health and Medical Research Council (NHMRC). Nutrient Reference Values for Australia and New Zealand: Including Recommended Dietary Intakes. Commonwealth of Australia: Canberra, 2006.

4 Food and Agricultural Organization (FAO), World Health Organization (WHO) Human Vitamin and Mineral Requirements: Report of a joint FAO/WHO expert consultation. Available at: ftp://ftp.fao.org/docrep/fao/004/y2809e/y2809e00.pdf (2001, accessed 4 December 2013).

5 Health Council of the Netherlands. Towards an Optimal Use of Folic Acid. Gezondheidsraad: Den Haag, 2008.
6 Food Safety Authority of Ireland. Recommended Dietary Allowances for Ireland 1999. Food Safety Authority of Ireland: Dublin, 1999.

7 Martin A. The 'apports nutritionnels conseillés (ANC)' for the French population. Reprod Nutr Dev 2001; 41: 119-128.

8 Scientific Advisory Committee on Nutrition (SACN) Dietary reference values (DRVs) for food energy and nutrients for the UK: panel on DRVs of the Committee on Medical Aspects of Food Policy (COMA). In Report on Health and Social Subjects Vol 41, 1991.

9 Herbert V. Minimal daily adult folate requirement. Arch Intern Med 1962; 110: 649-652.

10 Hoppner K, Lampi B. Folate levels in human liver from autopsies in Canada. Am J Clin Nutr 1980; 33: 862-864.

11 Scientific Committee on Foods. Reports of the Scientific Committee on Foods. Commission of the European Communities 1993, Directorate General Industry, Bruxelles.

12 Banerjee DK, Maitra A, Basu AK, Chatterjea JB. Minimal daily requirement of folic acid in normal Indian subjects. Indian J Med Res 1975; 63: 45-53.

13 Sauberlich HE, Kretsch MJ, Skala JH, Johnson HL, Taylor PC. Folate requirement and metabolism in nonpregnant women. Am J Clin Nutr 1987; 46: 1016-1028.

14 O'Keefe CA, Bailey LB, Thomas EA, Hofler SA, Davis BA, Cerda JJ et al. Controlled dietary folate affects folate status in nonpregnant women. J Nutr 1995; 125 2717-2725.

15 Nordic Council of Ministers. Nordic Nutrition Recommendations 2004. Integrating Nutrition and Physical Activity, 4th edn. Nordic Council of Ministers: Nord, Copenhagen, 2004, p 13.

16 Milne DB, Johnson LK, Mahalko JR, Sandstead HH. Folate status of adult males living in a metabolic unit: possible relationships with iron nutriture. Am J Clin Nutr 1983; 37: 768-773.

17 Guéguen, L. The 'Apports nutritionnels conseillés' (ANC) for the French population (chapter 2). French Food Safety Agency (AFSSA): Paris, 2001.

18 West AA, Caudill MA. Genetic variation: impact on folate (and choline) bioefficacy. J Int Vitam Nutr Res 2010; 80: 319-329.

19 Bailey, LB (ed). Folate in Health and Disease. Taylor \& Francis: Boca Raton, 2010.

20 Elmadfa I et al. Österreichischer Ernährungsbericht 2012. Bundesministerium für Gesundheit, Wien, 2012.

21 Selhub J, Jacques PF, Wilson PW, Rush D, Rosenberg IH. Vitamin status and intake as primary determinants of homocysteinemia in an elderly population. JAMA 1993; 270: 2693-2698.

22 Ubbink JB, Vermaak WJ, van der Merwe A, Becker PJ, Delport R, Potgieter HC. Vitamin requirements for the treatment of hyperhomocysteinemia in humans. J Nutr 1994; 124: 1927-1933.

23 Stanger O, Herrmann W, Pietrzik K, Fowler B, Geisel J, Dierkes J et al. consensus paper on the rational clinical use of homocysteine, folic acid and B-vitamins in cardiovascular and thrombotic diseases: guidelines and recommendations. Clin Chem Lab Med 2003; 41: 1392-1403.

24 Bønaa KH, Njølstad I, Ueland PM, Schirmer $\mathrm{H}$, Tverdal A, Steigen $\mathrm{T}$ et al. Homocysteine lowering and cardiovascular events after acute myocardial infarction. N Engl J Med 2006; 354: 1578-1588.

25 Homocysteine Lowering Trialists' Collaboration (HLTC). Dose-dependent effects of folic acid on blood concentrations of homocysteine: a meta-analysis of the randomized trials. Am J Clin Nutr 2005; 82: 806-812.

26 Toole JF, Malinow MR, Chambless LE, Spence JD, Pettigrew LC, Howard VJ et al. Lowering homocysteine in patients with ischemic stroke to prevent recurrent stroke, myocardial infarction, and death: the Vitamin Intervention for Stroke Prevention (VISP) randomized controlled trial. JAMA 2004; 291: 565-575.

27 Clarke R, Halsey J, Lewington S, Lonn E, Armitage J, Manson JE et al. Effects of lowering homocysteine levels with B vitamins on cardiovascular disease, cancer, and cause-specific mortality: Meta-analysis of 8 randomized trials involving 37485 individuals. Arch Intern Med 2010; 170: 1622-1631.

28 Clarke $R$, Bennett DA, Parish S, Verhoef $P$, Dötsch-Klerk M, Lathrop $M$ et al. Homocysteine and coronary heart disease: meta-analysis of MTHFR case-control studies, avoiding publication bias. PLoS Med 2012; 9: e1001177.

29 Gonzalez-Gross M, Prinz-Langenohl R, Pietrzik K. Folate status in Germany 1997-2000. Int J Vitam Nutr Res 2002; 72: 351-359.

30 Selhub J, Jacques PF, Dallal G, Choumenkovitch S, Rogers G. The use of blood concentrations of vitamins and their respective functional indicators to define folate and vitamin B12 status. Food Nutr Bull 2008; 29: S67-S73.

31 Bates CJ, Walmsley CM, Prentice A, Finch S. Use of medicines by older people in a large British national survey, and their relation to vitamin status indices. Public Health Nutr 1999; 2: 15-22.

32 Greenberg JA, Bell SJ, Guan Y, Yu Y. Folic acid supplementation and pregnancy: more than just neural tube defect prevention. Rev Obstet Gynecol 2011; 4: 52-59.

33 de Benoist B. Conclusions of a WHO technical consultation on folate and vitamin B12 deficiencies. Food Nutr Bull 2008; 29: S238-S244. 
34 Carmel R. Folic acid. In: Shils ME (ed). Modern Nutrition in Health and Disease. 9th edn. Williams \& Wilkins: Baltimore, 2006.

35 Stabler S. Clinical folate deficiency. In: Bailey LB (ed). Folate in Health and Disease. 2nd edn. Taylor \& Francis: Boca Raton, 2010.

36 Lamers Y. Folate recommendations for pregnancy, lactation, and infancy. Ann Nutr Metab 2011; 59: 32-37.

37 Souci, SW Fachmann, W Kraut, H Kirchhoff, E. Food Composition and Nutrition Tables. 7th, rev. and completed edn. Medpharm Scientific Publishers: Stuttgart, 2008.

38 Wright AJ, King MJ, Wolfe CA, Powers HJ, Finglas PM. Comparison of (6 S)-5methyltetrahydrofolic acid $v$. folic acid as the reference folate in longer-term human dietary intervention studies assessing the relative bioavailability of natural food folates: comparative changes in folate status following a 16-week placebocontrolled study in healthy adults. Br J Nutr 2010; 103: 724-729.

39 Durga J, Bots ML, Schouten EG, Grobbee DE, Kok FJ, Verhoef P. Effect of $3 \mathrm{y}$ of folic acid supplementation on the progression of carotid intima-media thickness and carotid arterial stiffness in older adults. Am J Clin Nutr 2011; 93: 941-949.

40 Jung $A Y$, Smulders $Y$, Verhoef $P$, Kok FJ, Blom H, Kok RM et al. No effect of folic acid supplementation on global DNA methylation in men and women with moderately elevated homocysteine. PLoS One 2011; 6: e24976.

41 Tighe P, Ward M, McNulty H, Finnegan O, Dunne A, Strain J et al. A dose-finding trial of the effect of long-term folic acid intervention: implications for food fortification policy. Am J Clin Nutr 2011; 93: 11-18.

42 Houghton LA, Gray AR, Rose MC, Miller JC, Hurthouse NA, Gregory JF. Long-term effect of low-dose folic acid intake: potential effect of mandatory fortification on the prevention of neural tube defects. Am J Clin Nutr 2011; 94: 136-141.

43 Venn BJ, Mann Jl, Williams SM, Riddell LJ, Chisholm A, Harper MJ et al. Assessment of three levels of folic acid on serum folate and plasma homocysteine: a randomised placebo-controlled double-blind dietary intervention trial. Eur J Clin Nutr 2002; 56: 748-754.

44 Allen LH. B vitamins in breast milk: relative importance of maternal status and intake, and effects on infant status and function. Adv Nutr 2012; 3: 362-369.
45 World Health Organization (WHO). The Optimal Duration of Exclusive Breast Feeding: A Systematic Review. Geneva, 2002.

46 Kramer MS, Kakuma R. Optimal duration of exclusive breastfeeding. Cochrane Database Syst Rev 2012; 8: CD003517.

47 Deutsche Gesellschaft für Ernährung (DGE). Referenzwerte für die Nährstoffzufuhr. 1. Aufl., 5., korrigierter Nachdr. Neustadt an der Weinstraße: Umschau, 2013.

48 Scholl TO, Johnson WG. Folic acid: influence on the outcome of pregnancy. Am J Clin Nutr 2000; 71: 1295S-1303S.

49 Busby A, Abramsky L, Dolk H, Armstrong B. Preventing neural tube defects in Europe: population based study. BMJ 2005; 330: 574-575.

50 Heseker $\mathrm{H}$. Folic acid and other potential measures in the prevention of neural tube defects. Ann Nutr Metab 2011; 59: 41-45.

51 Bechthold A, Albrecht V, Leschik-Bonnet E, Heseker H. Statement: evaluation of vitamin supplies in Germany. Data on vitamin intake. Ernährungs-Umschau 59: 324-336.

52 Timotijevic L, Barnett J, Brown K, Shepherd R, Fernández-Celemín L, Dömölki L et al. The process of setting micronutrient recommendations: a cross-European comparison of nutrition-related scientific advisory bodies. Public Health Nutr 2011; 14: 716-728.

53 European Food Safety Authority (EFSA). Tolerable Upper Intake Levels for Vitamins and Minerals. European Food Safety Authority: Parma, 2006.

54 Scientific Committee on Food (SCF) Opinion of the Scientific Committee on Food on the Tolerable Upper Intake Level of Folate http://ec.europa.eu/food/fs/sc/scf/ out80e_en.pdf (2000, accessed 4 December 2013).

This work is licensed under a Creative Commons AttributionNonCommercial-NoDerivs 3.0 Unported License. The images or other third party material in this article are included in the articles Creative Commons license, unless indicated otherwise in the credit line; if the material is not included under the Creative Commons license, users will need to obtain permission from the license holder to reproduce the material. To view a copy of this license, visit http://creativecommons. org/licenses/by-nc-nd/3.0/ 